\title{
The Existence of Dayak Customary Council in Settlement of Criminal Cases Based on Local Awareness (Decision Study of Dayak Customary Council Section No. 01/SMAD-PA/I/2011)
}

\author{
Esmi Warassih Pujirahayu ${ }^{1}$, Cahya Wulandari ${ }^{2}$ \\ \{esmiwarassih.undip@gmail.com ${ }^{1}$, cahyawulandari1984@gmail.com ${ }^{2}$ \} \\ Universitas Diponegoro, Indonesia ${ }^{1,2}$
}

\begin{abstract}
This article describes the Dayak Customary Council's existence in the resolution of criminal cases based on local wisdom (Study of Dayak Traditional Council Session Decision No. 01/SMAD-PA/I/2011) by describing the position of the Dayak customary court and analysis of the MADN decision against the Thamrin customary violators. The existence of indigenous peoples with their traditional rights has received constitutional recognition in Indonesia. Although customary courts' existence is gradually being eliminated due to the unification of law in Indonesia, in practice, several criminal cases are resolved through customary institutions. Settlement of criminal cases through customary institutions is considered more in accordance with existing local wisdom and can realize the values of justice desired by the parties in the case and restore the balance of the cosmos. One of them is the Dayak Customary Council's role, which passed Decision No. 01/SMAD-PA/I/2011 by basing the customary trial on the 1894 Tumbang Anoi Peace Agreement. Dayak Customary Institutions get legitimacy through the Regional Regulation of Palangka Raya City, which regulates Dayak Customary Institutions. Recognition of indigenous peoples' traditional rights can certainly not be separated from the customary laws that apply in the community and become the basis for the settlement of cases through customary institutions that exist as long as they have not been accommodated in state courts. Therefore, it is necessary to have synchronization, codification of recognition, and enforcement of customary law, which is still firmly adhered to by indigenous peoples in resolving criminal cases. It is done to restore further the cosmic balance (fulfilling justice between the parties in the case, the community, and the surrounding environment).
\end{abstract}

Keywords: Local Wisdom, Dayak Customary Institutions, Customary Law

\section{Introduction}

Now, customary courts' position is as far as possible being eliminated with legal unification. However, in reality, the customary courts are still alive among the indigenous peoples [1]. There are several customary courts, including the Gampong Court in Aceh, the Adat Court in Papua, the Nagari Adat in West Sumatra, and several adat institutions recognized by indigenous peoples, including the Dayak Customary Council in Palangka Raya City, Central Kalimantan. The existence of indigenous peoples and their traditional rights have received constitutional recognition in Article 18 B of the 1945 Constitution of the Republic of Indonesia. When customary courts must be abolished while the existence of indigenous peoples and their 
traditional rights are recognized in writing by the state, of course, it becomes a matter that is a dilemma [2].

Customary courts cannot be avoided at the level of practice in indigenous peoples because it has a philosophical relationship and is closely related to the local community's culture. Even in Central Kalimantan, there is the Central Kalimantan Provincial Regulation No. 1 of 2010 concerning Amendments to the Regional Regulation of the Province of Central Kalimantan No. 16 of 2008 concerning Dayak Customary Institutions in Central Kalimantan. The decision of the Dayak Customary Council Session No. 01/SMAD-PA/I/2011 which tried one of the sociologists, shows that the customary court, which in this case is the Dayak Customary Council (MADN), has an important position in the indigenous Dayak community. The process of solving cases through MADN is considered to restore the disturbed cosmic balance due to legal cases that have occurred. The customary judiciary is often considered to be more able to fulfill the community's sense of justice because decisions are based on the laws that live in the customary community itself [3].

Based on this background, the authors analyzed the Dayak Customary Council Session Decision No. 01/SMAD-PA/I/2011 and will elaborate further in the form of a discussion. This article describes the Dayak Customary Council's existence in the resolution of criminal cases based on local wisdom (Study of Dayak Traditional Council Session Decision No. 01/SMAD$\mathrm{PA} / \mathrm{I} / 2011$ ) by describing the position of the Dayak customary court and analysis of the MADN decision against the Thamrin customary violators.

\section{Research Methods}

The research was carried out with a qualitative research type through a philosophical normative approach based on the existing problems. Research is analyzed using interdisciplinary legal and social sciences, explaining an extensive legal phenomenon and its relation to power relations and the social, cultural, political, and economic context in which the law is located [4]. This study uses secondary data in the form of written rules owned by the Dayak indigenous people in Palangka Raya, the Dayak Customary Council's decision, several articles, and supporting books for discussion.

\section{The Role of Traditional Law in the Process of Settlement of Criminal Procedures}

\subsection{Position of Dayak Customary Judiciary}

Although the State Courts have obtained legitimacy to settle existing legal cases, customary courts are often used in resolving cases in certain indigenous peoples, especially in this case, the Dayak indigenous people. One of the procedures for resolving criminal cases is penal mediation that promotes restorative justice through an agreement between the parties with traditional characteristics of law, cultural pluralism, moral values, and religion [5]. In Central Kalimantan, customary courts play an important role in creating harmony between Dayak tribes. The existence of the Dayak Customary Institution itself has been recognized in the Regional 
Regulation of the Province of Central Kalimantan No. 16 of 2008 concerning Dayak Customary Institutions in Central Kalimantan.

The existence of customary courts confirms the validity of customary criminal law, which cannot be separated from the laws that live in society. According to Wignjosoebroto [6], customary law develops locally, is homogeneous, exclusive, generally unwritten, exists as general principles in specific communities, is used from generation to generation as a tradition that is believed to be in the resolution of cases that occur in society [7]. Customary crime (offense) is an act that violates feelings, a sense of justice, and collective decisions that exist in society, causing a cosmic imbalance in society and causing a reaction of indigenous people [8].

The Dayak Indigenous People are genuinely full of meaningful symbols, which are obeyed, trusted, guarded, and implemented to this day. The traditional Dayak languages are full of meaning about life, full of values that guide life. The process or social change shows the validity of the theory of the process or direction of social change, which assumes that growth symptoms mark human history. According to certain stages, when viewed from the Unilinear Theory of Evolution (Single Straight Line), humans and social experience development at first, a simple form then becomes complex even to the perfect stage [9]. Starting from symbols and slogans of meaningful ancestral heritage, interpreted as guidelines in the life maintained and trusted by the Dayak Indigenous people, which were then outlined in writing in the 1894 Tumbang Anoi Peace agreement Regional Regulation on Dayak Customary Institutions was formed.

The Tumbang Anoi Peace Agreement is an agreement to end conflicts that occur as a result of mengayau (finding and cutting off human heads). This agreement was attended by approximately 1000 people and it was agreed that there were 88 Articles of Customary Law and 8 Articles of the Life Rules of Belom Bahadat which regulate the life of the Dayak tribe to always be peaceful. The Tumbang Anoi Customary Agreement regulates the fine (singer) in the event of a violation and becomes the basis for resolving cases that occur among the Dayak Indigenous people in Central Kalimantan. Belom Bahadat and Budaya Betang, which has been passed down from generation to generation, has undergone such changes to become almost perfect and can be accepted, implemented, and obeyed even by people outside of the Dayak Indigenous community itself.

Philosophically, Belom Bahadat and Budaya Betang is a form of fulfilling adaptive needs, which arise and emanate from humans' nature as thinkers and morals. Humans need a culture that is a guiding system in living together. This integrative need includes the realization of a sense of justice, collective sentiment (togetherness), the creation of self-confidence and selfexistence in the environment [10]. Apart from being viewed from a social theory with an interpretive approach, the existence of customary courts can also be viewed from a legal perspective based on the role and function of the judiciary. Formal justice roles and functions are often considered overloaded, a waste of time, costly and unresponsive to public interests, or considered too formalistic and too technical [11].

The existence of the Dayak Customary Institution itself has been recognized in the Regional Regulation of the Province of Central Kalimantan No. 16 of 2008 concerning Dayak Customary Institutions in Central Kalimantan. The process of resolving criminal cases through customary institutions uses a deliberative approach to achieve peace between parties, also known as penal mediation. For some instances, the settlement uses customary courts that philosophically solve problems by giving existing decisions and ends the problems [12]. The problems that exist are ended through peace between the parties to break the chain of revenge and restore the cosmos' balance.

Ukur [13] states that the harmony and balance of the cosmos in the Dayak community are known as Hadat (adat), which includes life and behavior to create order and harmony. This 
custom has become a hereditary tradition, institutionalized in society, and functions to regulate the order of community life to become orderly and orderly [14]. It is certainly in line with the provisions of Article 2 of the 2019 RKUHP regarding the basic idea of balance by accommodating the laws that live in society as long as they do not conflict with Pancasila values and general principles recognized by the people of the nations. There is a balance between the values of justice and legal certainty and a balance of protection for victims and perpetrators.

Comparison for several variables between customary council and state's council are:

\begin{tabular}{|c|c|c|c|}
\hline No. & Variable & Customary Council & State's Council \\
\hline 1 & Scope & $\begin{array}{l}\text { Disputes in customary cases and } \\
\text { criminal cases among the members of } \\
\text { the indigenous peoples concerned, } \\
\text { also applies to people outside of the } \\
\text { Dayak indigenous peoples who } \\
\text { commit crimes related to the Dayak } \\
\text { indigenous peoples }\end{array}$ & Indonesian citizens \\
\hline 2 & The law being used & $\begin{array}{llll}\text { The } 1894 & \text { Tumbang Anoi Peace } \\
\text { Agreement } & & & \end{array}$ & $\begin{array}{l}\text { National law (for } \\
\text { criminal law is } \\
\text { KUHP, KUHAP) }\end{array}$ \\
\hline 3 & The consequences & $\begin{array}{l}\text { The resulting customary decisions are } \\
\text { final and binding between victim and } \\
\text { offender }\end{array}$ & $\begin{array}{l}\text { Judge decision has } \\
\text { permanent legal } \\
\text { force (in kracht van } \\
\text { gewijsde) }\end{array}$ \\
\hline 4 & Institution & $\begin{array}{l}\text { Traditional institution (Mantir Let } \\
\text { Adat, Dayak Customary Council, } \\
\text { National Dayak Customary Council }\end{array}$ & $\begin{array}{l}\text { Police, Prosecutors, } \\
\text { Courts }\end{array}$ \\
\hline
\end{tabular}

\subsection{Analysis of the Decision of the Dayak Customary Council}

Recognition of the Dayak Customary Institution had consequences in existing criminal cases' settlement process. A Customary Session was held against Thamrin Amal Tomagola, a sociologist who became an expert witness at the Bandung District Court trial. Thamrin's statement was related to the case of Ariel Peter Pan's porn video, which was stated in front of the Bandung District Court trial that it was deemed to have hurt the dignity of the Dayak Indigenous people who uphold customs, manners, and morals. Thamrin stated by referring to his research results those sexual relations before marriage are not something that violates the provisions and is common among the Dayak community. This statement offended the Dayak community. In Palangka Raya, more than 1000 Dayak residents staged a peaceful demonstration against Thamrin Amal Tomagola's statement. The Dayak action at the Palangka Raya City Roundabout was marked by the reading of the statement of the Dayak Customary Council (MADN) signed by the President of MADN. MADN considered Thamrin's statement offending the Dayak people's feelings, dignity, and worth.

The statement also insulted the Dayak people's customs, prioritizing the Belom Bahadat principle (living in manners and customs in various aspects of life). In solving the case, MADN asked Thamrin to take responsibility for what had been stated before the positive law and fulfill the demands of the Dayak customary law to avoid disharmony and horizontal conflicts that could damage the lives of the Dayak indigenous people. MADN also required Thamrin to openly apologize to all Dayak people through print and electronic media. Regarding this statement, Thamrin underwent a customary hearing in Palangka Raya City. 
The customary trial was conducted by MADN, which was named the Dayak Maniring Tuntang Menetes Hinting Bunu trial, which took place in the Betang Tingang Ngaderang (Betang Mandala Wisata) Room in Palangka Raya, Central Kalimantan between the Dayak people and Thamrin as a form of protecting the dignity of enforcing Dayak customary laws against delegitimation, demoralizing, insulting or insulting the Dayak people. Apart from that, the principle of Thamrin's statement is not in accordance with the Dayak community's view, which considers sexual relations without marital ties as normal, is considered to hurt feelings, undermines dignity, and is harassment of the customs of the Dayak tribe.

During the trial, Thamrin Amal Tomagola was found guilty. The hearing, which seven Dayak traditional leaders chaired, ordered Thamrin to retract his statement stating that ordinary Dayak people had husband and wife relations outside of the bond of marriage. Thamrin, who was present at the hearing, was willing to accept and agree to the customary court council's decisions, retracted his statement, and apologized to all Dayak people in front of the trial. Then, during the customary session, Thamrin also had to pay a fine for customary events worth IDR. 77,777,777 will be used for traditional events and must also revoke the research results related to this matter. Through a customary hearing witnessed directly by the President of the Dayak Customary Council (MADN), traditional leaders throughout Kalimantan, elements of the Central Kalimantan Muspida, and hundreds of people who witnessed the trial were named the Maniring Tuntang Manetes Hinting Bunu Customary Court (decided a prolonged grudge) between The Dayak and Tamrin Amal Tamagola people mean to break the prolonged grudge towards a better peace between the two parties. The trial was held for the first time and was final and binding. The customary trial aims to achieve peace, reconciliation, kinship and still maintain the dignity of the Dayak tribe as a whole. The charges against Thamrin were based on the Tumbang Anoi 1894 agreement.

Even though so far, the customary courts in Central Kalimantan have only been recognized by the Regional Regulation of the City of Palangka Raya and have been defeated by the law, in practice, it has become an alternative in settlement of cases pursued by the community to get the justice that is expected, not merely justice procedural but more on substantive justice. It is proven by the existence of 96 Dayak Damai Tumbang Anoi Adat Articles, which are the basis for the settlement of cases at the Dayak customary court, Central Kalimantan. Even singers (customary sanction) have grown along with developments in society, such as Katiramu (the term fine in customary provisions) refinement of what was initially called Jipen. Jipen is more about the meaning that after committing an offense, the perpetrator will receive sanctions from the victim in whatever form the victim wants.

At this time, Jipen has been known as Katiramu, which this term has followed changes throughout for good. The language that is not good is refined from jeepen to Katiramu. The amount of Katiramu is translated by the Damang agreement (customary figure); for example, in Palangka Raya, 1 Katiramu is equal to a nominal IDR 250,000, - and while according to Simpei Ilon as a Dayak traditional leader said that Katiramu could also be valued according to the current price of gold, gold 90 grams. Katiramu is based on the 96 Article of the Peace Agreement Tumbang Anoi. In the process of solving the case, the final agreement may not only be a fine given but also for cases of rape apart from being married. If it turns out that based on the meeting results between the parties, it is revealed that the perpetrator promised to marry the victim or had a previous relationship.

The customary judiciary, in this case, is an implementation process regarding the settlement and decision-making of a case based on the rules of customary law. The concept in customary law and customary justice is the root of restorative justice, which aims to restore the parties' position (perpetrators, victims, and society) as before the occurrence of a case [15]. 
Sociologically, customary courts are part of indigenous peoples' traditional rights, which still exist and are used by the community even though they do not receive recognition in statutory regulations [16]. Hence, the law cannot be properly understood if it is separated from social norms as part of living law, as Northop's opinion was quoted by Bodenheimer [17]. Often the laws are felt to be unable to bring about justice as expected by the community, primarily indigenous peoples, because the existing laws are static and do not follow society's developments [18]. The State of Indonesia's legal system, which is more inclined to civil law, makes law enforcement officials not accustomed to making legal discoveries so that indigenous people use their customary institutions to decide cases based on customary law.

\section{Conclusion}

It is a dilemma when indigenous peoples' position and their traditional rights are constitutionally recognized in the 1945 Constitution, but it cannot be appropriately implemented in practice. The existence of customary law is still recognized as long as it does not conflict with general provisions, Pancasila and Human Rights as stated in the provisions of Article 5 Paragraph (3) sub-b of the Emergency Law No. 1 of 1951. However, in practice, customary law does not get a legal umbrella in the process of implementing the settlement of criminal cases in particular, even though the enforcement of customary courts and autonomous courts have been abolished on the grounds of legal unification. It is what then the customary courts at the practical level are reborn to decide on a case based on the applicable customary law. The process of solving cases using customary courts based on applicable customary law is considered to be more able to realize the justice desired by certain indigenous peoples and restore the cosmos' balance. The settlement process is more based on peace and breaks the chain of revenge.

Therefore, further regulation is needed related to synchronization and accommodation of customary law in indigenous peoples at every stage of the existing criminal case settlement process. The shift in the purpose of punishment is more on the basic idea of balance, which applies written law and laws that live in society, not only legal certainty but prioritizing justice. Peaceful restoration of the parties' conditions is necessary so that a balance in society can be realized.

\section{Acknowledgements}

Author gratefully acknowledge that the research was financially supported by the Faculty of Law at Diponegoro University, Indonesia.

\section{References}

[1] N. Baroroh, "Peradilan Desa Adat sebagai Instrument Integral Pembangunan Hukum Nasional Ditinjau dari Undang-Undang No 62014 Tentang Desa," Supremasi Huk. J. Kaji. Ilmu Huk., vol. 4, no. 2, 2015.

[2] H. P. Wiratraman, "Perkembangan politik hukum peradilan adat," Mimb. Hukum-Fakultas Huk. Univ. Gadjah Mada, vol. 30, no. 3, pp. 488-503, 2018.

[3] Y. Arizona, "Kedudukan Peradilan Adat dalam Sistem Hukum Nasional," Disk. tentang 
memperkuat Peradil. Adat di Kalimantan Teng. untuk Penguatan Akses terhadap Keadilan, Selasa, vol. 11, 2013.

[4] S. Irianto, Meretas jalan keadilan bagi kaum terpinggirkan dan perempuan:(suatu tinjauan sociolegal). Jakarta: Lembaga Penerbit FEUI, 2009.

[5] N. Rochaeti and R. D. Sutanti, "Kontribusi Peradilan Adat dan Keadilan Restoratif Dalam Pembaruan Hukum Pidana Di Indonesia," Masal. Huk., vol. 47, no. 3, pp. 198-214, 2018.

[6] S. Wignjosoebroto, Pokok-pokok Pikiran tentang Empat Syarat Pengakuan Eksistensi Masyarakat Adat, dalam Hilmi Rosyida dan Bisariyadi (eds.), Inventarisasi dan Perlindungan Hak Masyarakat Hukum Adat. Jakarta: Komnas HAM, Mahkamah Konstitusi RI, dan Departemen Dalam Negeri., 2005.

[7] G. F. Y. Astuti, "Relevansi Hukum Pidana Adat Dalam Pembaharuan Hukum Pidana di Indonesia," Pandecta Res. Law J., vol. 10, no. 2, pp. 195-214, 2015.

[8] K. Kastubi, "Tindak Pidana Adat 'Logika Sanggraha' di Bali," J. Spektrum Huk., vol. 15, no. 1, pp. 112-123, 2018.

[9] E. Digdoyo, S. Pd, and M. Hum, Ilmu sosial dan budaya dasar. Bogor: Ghalia Indonesia, 2015.

[10] M. Thohir, Bahan Kuliah Teori-Teori Sosial. Semarang: Program Doktor Ilmu Hukum Universitas Diponegoro, 2014.

[11] G. Garry, Tinjauan Terhadap Penyelesaian Sengketa Dalam Seri: Dasar Hukum Ekonomi 2 Arbitrase Indonesia. Jakarta: Ghalia Indonesia, 1995.

[12] N. Mardhiah, "Penyelesaian Perselisihan Adat Istiadat dalam Kehidupan Masyarakat di Kabupaten Aceh Barat Berdasarkan Tinjauan Peraturan Gubernur Aceh," Community Pengawas Din. Sos., vol. 2, no. 2, 2018.

[13] F. Ukur, "Tantang-jawab suku Dayak: Suatu penyelidikan tentang unsur-unsur yang menyekitari penolakan dan penerimaan Injil di kalangan Suku-Dayak dalam rangka sejarah Gereja di Kalimantan : 1835-1945," Doctoral dissertation, Universitas Gadjah Mada, 1971.

[14] A. Aloy, Semangat Dayak: catatan perjuangan politik Partai Persatuan Dayak, 1945-1963. Jakarta: Penerbit Buku Kompas, 2019.

[15] E. A. Zulfa, "Keadilan Restoratif dan Revitalisasi Lembaga Adat di Indonesia," Indones. J. Criminol., p. 4199, 2010.

[16] N. Amalia, M. Mukhlis, and Y. Yusrizal, "Model Penyelesaian Sengketa dan Peradilan Adat di Aceh,” J. Huk. Ius Quia Iustum, vol. 25, no. 1, pp. 159-179, 2018.

[17] E. Warassih, K. K. Medan, and Mahmutarom, Pranata Hukum: sebuah telaah sosiologis. Semarang: Suryandaru Utama, 2005.

[18] W. Winarsih and C. Wulandari, "Relevansi Yuridis Mediasi Penal dalam Penyelesaian Tindak Pidana pada Masyarakat Suku Samin," IJCLS (Indonesian J. Crim. Law Stud., vol. 1, no. 1, pp. 18-38, 2017. 